\title{
Seasonal burning and mowing impacts on Sporobolus wrightii grasslands
}

JERRY R. COX

\section{Abstract}

Land managers have recommended burning or mowing big sacaton (Sporobolus wrightil) grasaland in either fall or winter for 100 years. The greatest potential for natural fire would have occurred when lightning strike frequency peaked in summer. The objective of this study was to determine how burning and mowing in fall (October), summer (July) and winter (February) influences big sacaton forage quantity and quality. Plants defoliated in fall produced leaves within 215 to 245 days, those defoliated in summer within 3 days, and those in winter within 20 days. Green and dead forage that accumulated after the burning and mowing in the same seasons were similar, but differences occurred among seasons. Green and dead forage following summer treatments were similar to that on untreated areas within 2 or 3 summer growing seasons, but were reduced on fall and winter treatments. Crude protein in green forage was 3 to $5 \%$ greater in treated plants than in untreated plants for 6 weeks after treatment, but forage quality increases were temporary. Burning or mowing at any season removes green forage available to livestock and reduces the amount of green forage that may accumulate for at least 2 summer growing seasons.

Key Words: big sacaton, riparian grasalands, southeastern Arizona

Native perennial grasses growing on upland semidesert grasslands of the southwestern United States and northern Mexico are dormant in fall, winter, and spring (Humphrey 1960). In contrast, big sacaton (Sporobolus wrightii), a robust perennial bunchgrass that grows in lowland areas where flood waters accumulate, produces small quantities of green forage when other grasses are dormant (Cox 1984).

In the past, lactating cows were forced to graze big sacaton grasslands when upland grasses were dormant, because few other green forage sources were available (Griffiths 1901). The small

\footnotetext{
Author is range scientist, USDA-Agricultural Research Service, Aridland Watershed Management Research Unit, 2000 E. Allen Road, Tucson, Arizona 85719.

Appreciation is extended to R.M. Madrigal, B.B. Buck, M.H. Martin-R., R. Martin, J.M. Parker, J.M. Ruyle, and T.J. Post for field assistance; Dr. Gary Richardson and Stephan Roth for computer analysis; Drs. Howard L. Morton and T.N. Johnsen, Jr., for technical assistance; the families of John and MacFarlane Donaldson at the Empire Ranch for their cooperation; and ANAMAX Mining Company for permission to use their land.

Manuscript accepted 3 September 1987.
}

quantities of green forage were difficult for grazing animals to obtain since dead forage limited utilization (Haferkamp 1982). Land managers eliminated dead forage by either burning or mowing in fall or winter (Griffiths et al. 1915) and treatments applied in these seasons were and are currently thought to stimulate new growth and enhance forage quality (Humphrey 1958). Studies designed to evaluate treatment and season effects on big sacaton forage quantity and quality do not exist, although, both practices have been applied in the 2 seasons for 100 years.

Big sacaton grows rapidly from late July to mid-September when summer rainfall peaks and daytime temperatures range from 25 to $30^{\circ} \mathrm{C}(\mathrm{Cox} 1984,1985)$. Prior to the summer rainfall peak the majority of the big sacaton phytomass is dead, daytime temperatures exceed $35^{\circ} \mathrm{C}$, and lightning frequency peaks (Osborn 1983, Cox and Morton 1986). Therefore, lightning-caused fires have been most common in early summer (Hastings and Turner 1965).

The objectives of this study were to (1) determine how burning or mowing big sacaton in either winter, summer, or fall affects forage quantity and quality, and (2) discuss the results in relation to various management strategies.

\section{Methods and Materials}

\section{Site Description}

In January 1980, an experiment was initiated in a big sacaton grassland about $80 \mathrm{~km}$ south of Tucson, $\left(31^{\circ} 47^{\prime} \mathrm{N}\right.$. Lat., $110^{\circ} 37^{\prime}$ W. Long.). Soil at the site is a Pima silty clay loam, with a sandy subsoil (thermic Typic Haplustolls) (Richardson et al. 1979). The soil, developed from recent alluvium that weathered from mixed rocks, is moderately alkaline, slightly calcareous and greater than 2 $\mathrm{m}$ deep. Elevation is about $1,370 \mathrm{~m}$ and average annual precipitation is $400 \mathrm{~mm}$ (Sellers and Hill 1974). Approximately $60 \%$ of the annual precipitation comes as rain between July and September, and $40 \%$ comes as either rain or snow from October to April. Day-time temperatures average $30^{\circ} \mathrm{C}$ in summer and night-time temperatures are often below $0^{\circ} \mathrm{C}$ in winter.

A 2-ha study site was fenced within a 500 -ha big sacaton pasture. The pasture was lightly grazed by cattle and horses in either fall, winter, or spring between 1976 and 1980 , and moderately grazed by 
cows and calves in winter between 1935 and 1975 . From about 1885 to 1934 , the pasture was unfenced and grazed yearlong.

Charcoal scars on cottonwood (Populus deltoides) and mesquite (Prosopis juliflora) trees within the pasture indicate the occurrence of fires. Relatives and associates of previous owners acknowledge the occurrence of lightning fires in the summers of 1920,1935 , and 1950 and either fall or winter control burns at 5 to 10 -year intervals between 1935 and 1975 .

\section{Presampling}

Ten, 0.3 by $2.9-\mathrm{m}$ sampling areas were randomly located in 15 by 15-m plots, and all forage harvested at the soil surface. Forage in each sampling area was weighed, dried at $105^{\circ} \mathrm{C}$ for $48 \mathrm{~h}$, and reweighed. Forage dry weight (fuel load) and fine fuel water content (expressed as a \% of dry weight) were averaged by plot.

\section{Defoliation Treatments}

Plots were either burned with a headfire or mowed to a $5-\mathrm{cm}$ stubble height in winter (February 6), summer (July 10), and fall (October 2) 1980, 1981, and 1982. The time from ignition to total forage consumption or shredding of all above-ground forage was recorded by plot. During each treatment wind speed and air temperature were recorded at 10 -s intervals and averaged by plot.

\section{Forage Sampling}

Twenty, 0.3 by 2.9 -m sampling areas were randomly selected for sampling at 6-week intervals for 3 years after treatment. Big sacaton plants in 4 sampling areas were harvested at the soil surface and separated into green and dead forage; no area was resampled during the experiment. Separated samples were weighed in the field and a modified weight-estimate technique used to estimate both green and dead forage in 16 sampling areas (Pechanec and Pickford 1937). Separated samples were dried in a forced-air oven at $40^{\circ} \mathrm{C}$ for $48 \mathrm{~h}$ and weighed. Regression techniques were used to estimate dry weights from estimated field weights (Campbell and Cassady 1949). These values were used to calculate green and dead forage.

\section{Foraze Quality}

Green and dead forage samples were composited by plot into either a total green or total dead sample, and each ground to pass through a 1-mm screen. Samples were thoroughly mixed and 3 subsamples digested and analyzed for total nitrogen using a Technicon ${ }^{1}$ digestor and a continuous flow auto-analyzer (Schuman et al. 1973). Total nitrogen was multiplied by 6.25 and expressed as crude protein.

\section{Design and Statistical Analysis}

Treatments were arranged in a split block design with 3 replications. The 3 years were randomized as blocks within a replication and the 7 treatments were randomized within years. Therefore, years are main plots and treatments are subplots.

'Mention of a commercial product is for the reader's convenience and does not imply endorsement by the USDA-Agricultural Research Service.
At some sampling dates green and dead forage amounts from untreated plots were from 5 to 1,000 times greater than for treated plots. When these conditions existed, the population variances (treated versus untreated) were tested for homogeneity. If the 2 populations had a common variance, the data were pooled and subjected to analysis of variance; when population variances differed $(P \leq 0.05)$, data from untreated plots were analyzed separately from treated plots. When year, treatment, or year by treatment interactions were significant $(P \leq 0.05)$ means were separated by a Least Significant Difference test (Steel and Torrie 1960).

In big sacaton grasslands green forage accumulates and dead forage decomposes in late August (Cox 1984). Forage quantities are dependent upon summer rainfall and are highly variable among years (Cox 1985). Therefore, year by treatment comparisons are presented only for the 21 August sampling dates which occurred 1, 2, and 3 years following fall burning and mowing.

\section{Results and Discussion}

Above-ground big sacaton phytomass (green plus dead forage) was highly variable among years and seasons, and varied from 2,800 to approximately $5,000 \mathrm{~kg} /$ ha (Table 1). Green forage was less than $15 \%$ of the big sacaton phytomass in winter and summer. Fuel water content varied from 10 to $30 \%$, and treatment times averaged 68 and $267 \mathrm{~s}$, respectively, for burning and mowing. Green forage averaged $55 \%$ of the phytomass in fall, fuel water content averaged $48 \%$, and treatment times averaged 163 and $438 \mathrm{~s}$, respectively for burning and mowing.

\section{Quantity and Quality of Green Forage}

Big sacaton leaves began to appear within 20 days on plants defoliated in winter and within 3 days on plants defoliated in summer. Burning or mowing in either winter or summer appeared to stimulate green leaf production, and a lush carpet of green leaves was present from April to August on winter-defoliated plots and from July to August on summer-defoliated plots. Green forage availability on 21 August (24 weeks after winter defoliation and 6 weeks after summer defoliation) for the 3 treatment years (Fig. 1), however, was consistently greater $(P \leq 0.05)$ on untreated plots, intermediate on winter-defoliated plots, and less on summerdefoliated plots.

Burning or mowing at any season removes big sacaton phytomass and exposes the crown, but fall defoliations leave the crown exposed in winter when night-time temperatures are frequently below $0^{\circ} \mathrm{C}$ (Cox 1984). Fall defoliations (1) remove the small quantities of green forage available to livestock in fall and winter and (2) reduce green forage availability in early spring (Fig. 1). The result is the complete loss of the grazing resource for 215 to 245 days after fall defoliation.

Observations made during this 6-year study suggest that big sacaton initiates leaf production in summer and winter. Summer growth occurs from May to August, and few leaves remain green during fall and winter. Most summer leaves become dormant in

Table 1. Fuel characteristics, environmental conditions, and forage removal time when burning and mowing bis sacaton during 3 seasons in 1980 , 1981 and 1982 in southeastern Arizona.

\begin{tabular}{|c|c|c|c|c|c|c|c|}
\hline \multirow[b]{2}{*}{ Season } & & \multirow[b]{2}{*}{ Fuel loam } & \multirow[b]{2}{*}{ Fuel water content } & \multicolumn{2}{|c|}{ Removal time } & \multirow[b]{2}{*}{ Wind speed } & \multirow[b]{2}{*}{ Air temperature } \\
\hline & & & & Burn & Mow & & \\
\hline \multirow{4}{*}{ Winter } & & -kg/ha- & $-\%$ & \multicolumn{2}{|c|}{$\longrightarrow$} & $-\mathrm{km} / \mathrm{hr}-$ & ${ }^{\circ} \mathrm{C}$ \\
\hline & 1980 & 3,945 & 10 & 60 & 300 & 10 & 18 \\
\hline & 1981 & 2,975 & 30 & 80 & 250 & 10 & 10 \\
\hline & 1982 & 4,055 & 10 & 50 & 275 & 10 & 10 \\
\hline \multirow[t]{3}{*}{ Summer } & 1980 & 5,095 & 25 & 80 & 250 & 14 & 30 \\
\hline & 1981 & 2,800 & 20 & 65 & 275 & 15 & 30 \\
\hline & 1982 & 3,985 & 20 & 70 & 250 & 8 & 29 \\
\hline \multirow[t]{3}{*}{ Fall } & 1980 & 3,475 & 45 & 180 & 500 & 10 & 20 \\
\hline & 1981 & 4,700 & 55 & 145 & 450 & 10 & 25 \\
\hline & 1982 & 3,750 & 45 & 165 & 365 & 8 & 19 \\
\hline
\end{tabular}




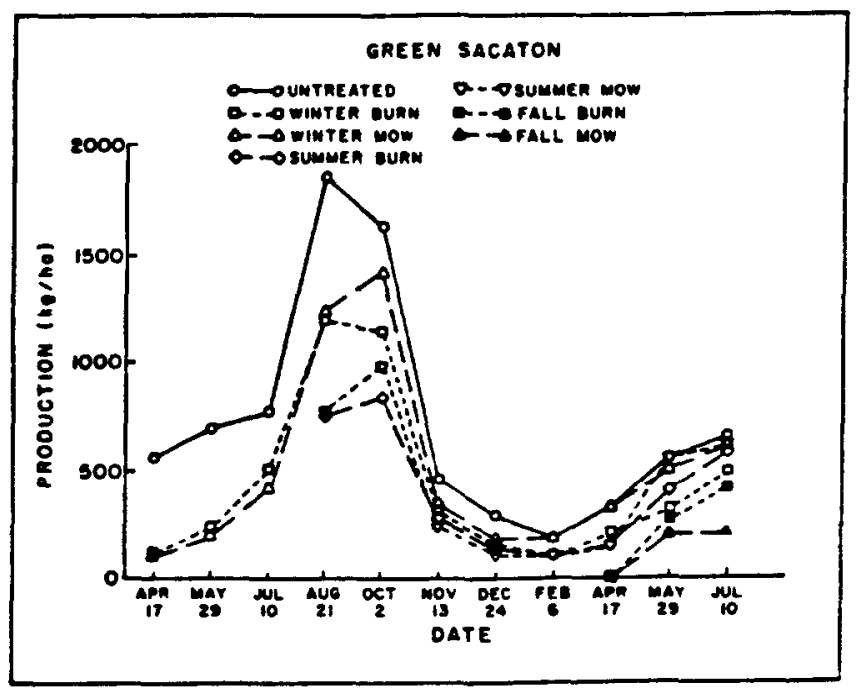

Fis. 1. Green big sacaton forage following burning or mowing in either winter, summer, or fall during 1980,1981, and 1982 at a riparian site in southeastern Arizona.

September and October when the sheaths elongate and roll into a cylinder. During winter a new leaf develops within the rolled sheath, and in early spring (March to April) leaves expand and the dead sheath shatters. Fall defoliations remove summer leaves which provide green forage during fall and winter, inhibit winter leaf formation and development, and green big sacaton forage production remains at zero for 7 to 8 months.

In the first and second summer growing season after treatment, big sacaton green forage accumulated more rapidly on summer than on winter- or fall-defoliated plots (Table 2), but differences

Table 2. Big ancaton green forage at the peak of the summer growing season (21 August) one, two, and three years after treatment.

\begin{tabular}{|c|c|c|c|c|c|}
\hline \multirow{2}{*}{\multicolumn{2}{|c|}{$\begin{array}{l}\text { Number of grow- } \\
\text { ing' seasons after Season and } \\
\text { treatment } \\
\end{array}$}} & \multicolumn{3}{|c|}{ Treatment year } & \multirow[b]{2}{*}{ LSL } \\
\hline & & 1980 & 1981 & 1982 & \\
\hline \multirow[b]{2}{*}{1} & & & $-\mathrm{kg} / \mathrm{ha}$ & & \\
\hline & $\begin{array}{l}\text { Winter burning } \\
\text { Winter mowing } \\
\text { Summer burning } \\
\text { Summer mowing } \\
\text { Fall burning } \\
\text { Fall mowing } \\
\text { Untreated }\end{array}$ & $\begin{array}{r}735 \\
765 \\
865 \\
915 \\
725 \\
665 \\
1,900\end{array}$ & $\begin{array}{r}615 \\
560 \\
770 \\
790 \\
665 \\
660 \\
2,600\end{array}$ & $\begin{array}{r}400 \\
650 \\
700 \\
760 \\
260 \\
575 \\
1,695\end{array}$ & 205 \\
\hline 2 & $\begin{array}{l}\text { Winter burning } \\
\text { Winter mowing } \\
\text { Summer burning } \\
\text { Summer mowing } \\
\text { Fall burning } \\
\text { Fall mowing } \\
\text { Untreated }\end{array}$ & $\begin{array}{r}850 \\
840 \\
925 \\
995 \\
805 \\
895 \\
1,365\end{array}$ & $\begin{array}{r}745 \\
780 \\
935 \\
965 \\
755 \\
655 \\
1,720\end{array}$ & $\begin{array}{r}690 \\
550 \\
850 \\
830 \\
575 \\
715 \\
1,705\end{array}$ & 150 \\
\hline 3 & $\begin{array}{l}\text { Winter burning } \\
\text { Winter mowing } \\
\text { Summer burning } \\
\text { Summer mowing } \\
\text { Fall burning } \\
\text { Fall mowing } \\
\text { Untreated }\end{array}$ & $\begin{array}{r}615 \\
735 \\
1,590 \\
1,440 \\
745 \\
840 \\
1,650\end{array}$ & $\begin{array}{r}595 \\
655 \\
1,450 \\
2,000 \\
890 \\
990 \\
1,845\end{array}$ & $\begin{array}{r}695 \\
620 \\
1,375 \\
1,530 \\
790 \\
630 \\
2,000\end{array}$ & 525 \\
\hline
\end{tabular}

'Data were collected in August, one, two and three growing seasons following October (Fall) treatments.

2When a bracket includes only the treatments, the variances between treated and untreated means were not homogeneous. Therefore, a separate ANOVA was used for each set. Means in each set that differ more than the given Least Significant Difference value are significantly different at $P \leq 0.05$. among seasons and treatments occurred infrequently. By the third summer growing season, green forage on summer-defoliated plots was usually greater than on winter and fall-defoliated plots, and generally equivalent to untreated plots. The accelerated growth on summer-defoliated plots supports the hypothesis that summer defoliations, whether by burning or mowing, have the least negative impact on future plant production. Recommended winter and especially fall defoliations (Griffiths 1901, Humphrey 1958), have a detrimental effect on plant production for at least 3 summer growing seasons.

Burning and mowing at any season removes green big sacaton forage available to livestock and reduces the amount of green forage for at least the next 2 years (Table 2). These results are from measurements taken in summers when rainfall was either above, below, or equal to the long-term average (Sellers and Hill 1974, Cox 1984, Cox and Morton 1986). These data do not agree with the prevailing belief that green big sacaton forage production is stimulated by removing dead forage (Humphrey 1958).

Big sacaton green forage quality temporarily improves after burning or mowing in each of the 3 seasons (Fig. 2). Crude protein

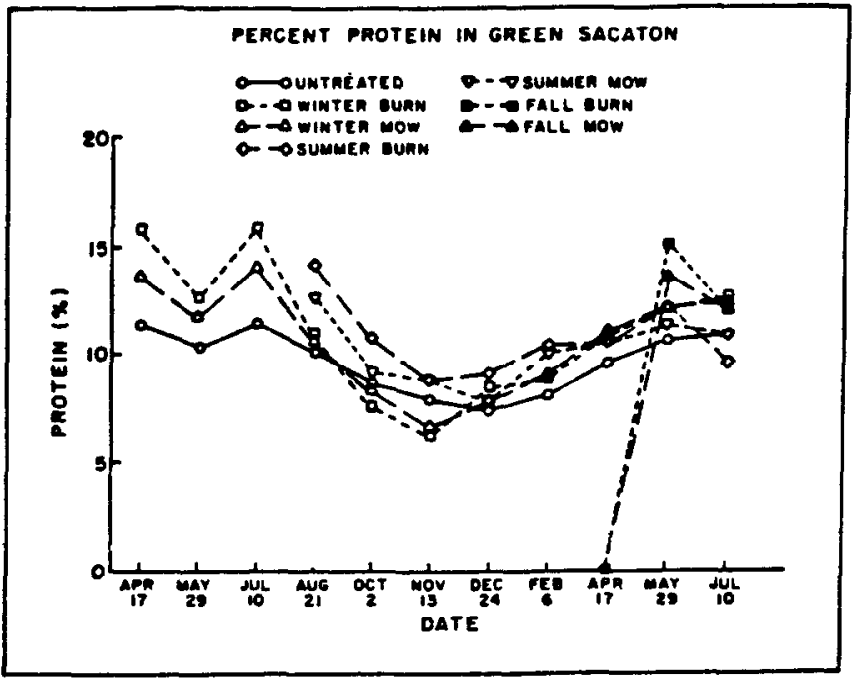

Fis. 2. Crude protein content of green big sacaton forage following burning or mowing in either winter, summer or fall during 1980,1981 and 1982 at a riparian site in southeastern Arizona.

content of green forage was greatest on burned, intermediate on mowed, and least on untreated plots when measured 6 weeks after winter, summer, and fall defoliations. Differences among treatments did not occur after 6 weeks. Green forage availability and quality improves after either burning (Bock and Bock 1978) or mowing (Haferkamp 1982), and daily gains of steers grazing green forage only can be expected to exceed those of steers grazing green plus dead forage (Cox and Morton 1986).

\section{Quantity and Quality of Dead Forage}

Green forage that accumulates in summer following winter or summer defoliation becomes dead forage in fall. Dead forage quantities declined gradually during the second spring and early summer (Fig. 3). The remaining dead forage disappears following the summer rains and active plant growth in late July and August (Table 3). On fall-defoliated plots the transfer of green to dead forage occurs aftr the first summer growing season measurement, thus, no dead forage was recorded on 21 August.

In the second and third summer growing season, big sacaton dead seed stalks accumulated more rapidly on summer-defoliated plots than on winter and fall-defoliated plots. Therefore, dead forage quantities on summer-defoliated plots exceeded those on winter and fall-defoliated plots (Table 3), but differences were not always significant. Dead forage is not an ideal forage resource 


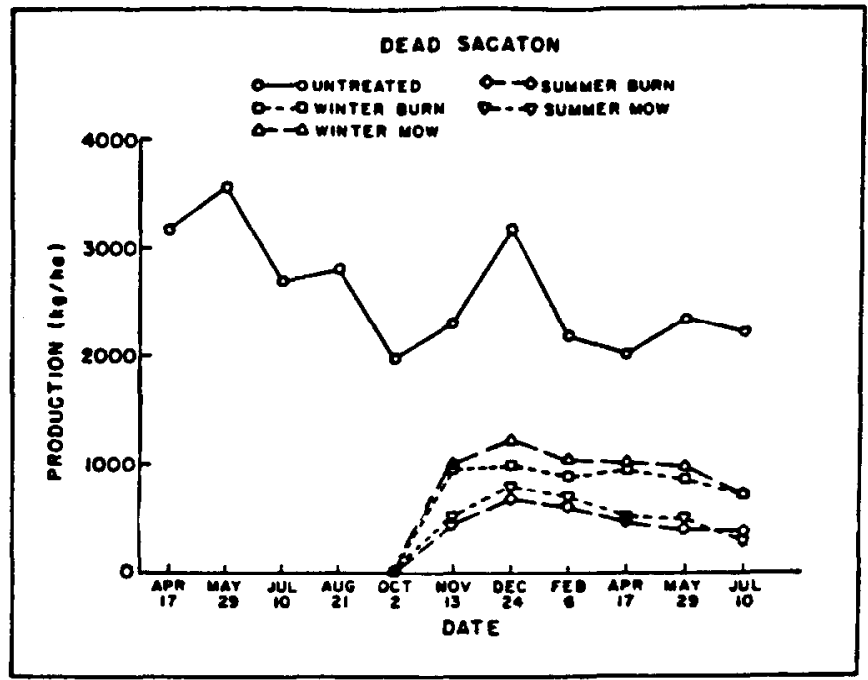

Fis. 3. Dead big sacaton forage following burning or mowing in either winter, summer, or fall during 1980,1981, and 1982 at a riparian site in southeastern Arizona. Dead forage accumulations on fall treatments occurred after the second 10 July sampling date.

Table 3. Big sacaton dead forage at the peak of the summer growing season (21 Ausuat), one, two, and three years after treatment.

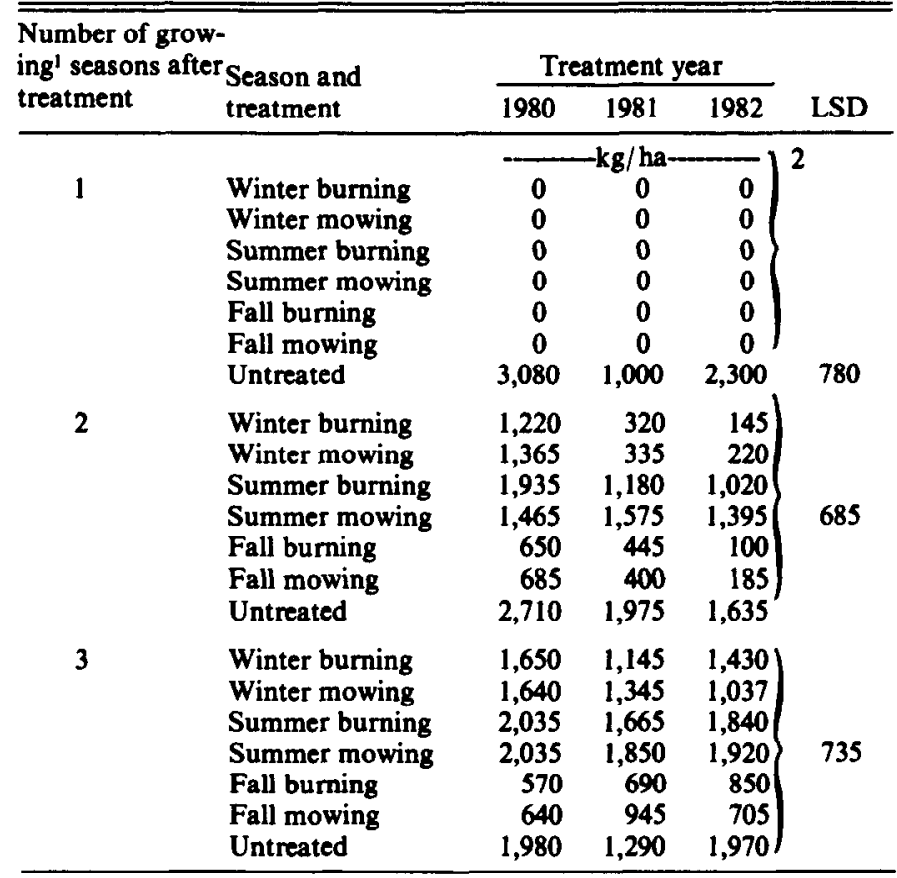

'Data were collected in August, one, two and three growing seasons following October (fall) treatments.

2When a bracket includes only the treatments, the variance between treated and untreated means were not homogeneous. Therefore, a separate ANOVA was used for each data set. Means in each set that differ more than the given Least Significant Difference Value are significantly different at $P \leq 0.05$.

because crude protein content annually varies from 3 to $6 \%$ (data not shown), but its removal influences pasture stocking rate. Cox and Morton (1986) and have shown that winter defoliations (burning or mowing) cause a three-fold decrease in summer stocking rates, while daily steer gains on defoliated pastures were only one-third greater than on an untreated pastures.

\section{Management Implications}

Before 1880, big sacaton existed in pure stands along the riparian channels and tributaries within the North American semidesert grassland (Griffiths 1901). These grasslands acted as a continuous dam which naturally spread floodwaters from nearby uplands and more distant mountainous areas (Renard et al. 1985), trapped sediments which leveled valley floors (Hubbell and Gardner 1950), and contributed to the formation of shallow water tables and perennial streams (Cooke and Reeves 1976).

Big sacaton currently occupies less than $5 \%$ of its original area of distribution (Humphrey 1960) because the processes which supplied additional soil moisture were disrupted by channel formation (Cooke and Reeves 1976). Under current conditions, winter and fall defoliations should be discontinued.

Big sacaton plants defoliated in summer may be expected to recover to pretreatment levels within 2 or 3 years. In summer, livestock prefer upland grasses to the regrowth of either burned or mowed big sacaton; even though green forage is abundant, available, and nutritious (Cox 1985, Haferkamp 1982). If fencing is using to separate big sacaton grasslands from upland grasslands, cattle will graze untreated big sacaton and gain from 0.50 to 0.75 $\mathrm{kg} /$ day in summer (USDA-ARS, unpublished data). Without fencing, cattle overgraze uplands and gain from 0.40 to 0.45 $\mathrm{kg}$ /day when forced to graze big sacaton (Cox and Morton 1986).

\section{Literature Cited}

Bock, C.E., and J.H. Bock. 1978. Response of birds, small mammals, and vegetation to burning sacaton grasslands in southeastern Arizona. J. Range Manage. 31:296-300.

Campbell, J.B., and J.T. Casady. 1949. Determining forage weight on southern forest ranges. J. Range Manage. 2:30-32.

Cooke, R.U., and R.W. Reeves. 1976. Arroyos and environmental change in the American southwest. Clarendon Press, Oxford.

Cox, J.R. 1984. Shoot production and biomass transfer of big sacaton (Sporobolus wrightii). J. Range Manage. 37:377-380.

Cox, J.R. 1985. Above-ground biomass and nitrogen quantities in big sacaton (Sporobolus wrightii) grassland. J. Range Manage. 38:273-276.

Cox, J.R., and H.L. Morton. 1986. Big sacaton (Sporobolus wrightii) riparian grassland management: Annual winter burning, annual winter mowing, and spring-summer grazing. J. Applied Agr. Res. 1:105-111.

Grifiths, D. 1901. Range improvement in Arizona. USDA-Bureau of Plant Industry, Bull. 4.

Griffiths, D., G.L. Bidwell, and C.E. Goodrich. 1915. Native pasture grasses of the United States. USDA, Bull. 201.

Haferkamp, M.R. 1982. Defoliation impacts on quality and quantity of forage harvested from sacaton (Sporobolus wrightii Monro). J. Range Manage. 35:26-31.

Hastings, J.R., and R.M. Turner. 1965. The changing mile. Univ. of Ariz. Press, Tucson.

Hubbell, D.S., and J.L. Gardner. 1950. Effects of diverting sediment-laden runoff to range and croplands. USDA Tech. Bull. 1012.

Humphrey, R.R. 1958. The desert grassland. Bot. Rev. 24:193-253.

Humphrey, R.R. 1960. Arizona range grasses. Ariz. Agr. Exp. Sta. Bull. 298.

Osbom, H.B. 1983. Precipitation characteristics affecting hydrologic response of southwestern rangelands. USDA-Agr. Res. Ser. ARM-W-34.

Pechanec, J.F., and G.D. Picliford. 1937. A weight estimate method for determination of range or pasture production. J. Amer. Soc. Agron. 28:894-904.

Renard, K.G., J.R. Cox, and D.F. Post. 1985. Effects of soil erosion on productivity in the southwest, p. 321-334. In:R.F. Follett and B. Steward (eds.), Soil Erosion and Crop Productivity. ASA-CSSA-SSSA, Madison, Wis.

Richardson, M.L., G.D. Clemmons, and J.C. Walker. 1979. Soil survey of Santa Cruz and parts of Cochise and Pima Counties, Arizona. Nat. Coop. Soil Sur., USDA-Soil Conservation Ser., Forest Ser., and Ariz. Exp. Sta., Washington, DC.

Schuman, G.I., M.A. Standley, and D. Knudsen. 1973. Automated total nitrogen analysis of soil and plant samples. Soil Sci. Soc. Amer. Proc. 37:480-481.

Sellers, W.D., and R.H. Hill. 1974. Arizona climate (1931-1972). Univ. of Ariz. Press, Tucson.

Steel, R.G.D, and J.H. Torrie. 1960. Principles and procedures of statistics. McGraw Hill, New York. NY. 